\title{
Tahap Preliminary Research Pengembangan Media Pembelajaran Berbasis Komputer pada Materi Transformasi SMA/MA
}

\author{
Arifa Rahmi ${ }^{1, a)}$, Armiati ${ }^{2, b)}$, dan Hendra Syarifuddin ${ }^{3, c)}$ \\ ${ }^{1}$ Mahasiswa Pascasarjana FMIPA UNP, Padang, Indonesia \\ ${ }^{2,3}$ Staf Pengajar Pascasarjana FMIPA UNP, Padang, Indonesia
}

Email penulis: a) rahmiarifa31@gmail.com; ${ }^{\text {b) }}$ armiati_math_unp@yahoo.co.id; ${ }^{c}$ hendrasy@yahoo.com

\begin{abstract}
The human life aspect's is concerned with measure activities that geometry context, such as study of plane, space, size and position. Students' faced the difficulty in understanding concept and interpreting of direction of a transformed geometry object. To solved this difficulty student's need mathematics learning media which able to clarify transformation context. The aim of this research to know the characteristics and description of mathematics learning media of based computer on geometry transformation context which is should be preliminary research phase. This research was using Plomp's model. This model consists to preliminary research phase. This research found that mathematics learning media of based computer on the geometry transformation context was preliminary research phase.
\end{abstract}

Keywords: Mathematics learning media, transformation context, preliminary research

\begin{abstract}
Abstrak
Setiap aspek kehidupan manusia berkaitan dengan aktivitas mengukur, seperti mempelajari bentuk, ruang, ukuran dan posisi. Kebanyakan peserta didik kesulitan dalam memahami konsep dan mengidentifikasi arah suatu objek geometri yang ditransformasikan. Untuk menyelesaikan permasalahan tersebut, peserta didik membutuhkan media pembelajaran matematika yang dapat memperjelas materi transformasi. Tujuan dari penelitian ini adalah untuk mengetahui karakteristik dan deskripsi media pembelajaran berbasis komputer pada materi transformasi geometri yang memenuhi tahap penelitian pendahuluan. Penelitian ini menerapkan model Plomp. Model ini membahas pada tahap penelitian pendahuluan. Penelitian ini telah menemukan media pembelajaran berbasis komputer pada materi transformasi geometri yang telah memenuhi tahap penelitian pendahuluan.
\end{abstract}

Kata kunci: Media pembelajaran matematika, materi transformasi, penelitian pendahuluan.

Copyright (c) 2021 Rahmi, Armiati, Syarifuddin

$\square$ Corresponding author:

Email Address: rahmiarifa31@gmail.com

Received 28 Januari 2018, Accepted 24 Februari 2021, Published 28 Februari 2021

\section{PENDAHULUAN}

Salah satu cabang materi geometri yang mengkaji tentang perubahan pada posisi, ukuran atau bentuk adalah transformasi. Edwards (1997) dalam artikelnya menyatakan bahwa belajar transformasi geometri memberikan kesempatan bagi peserta didik untuk mengembangkan kemampuan visualisasi spasial, penalaran geometri dan kemampuan pembuktian matematis.

Dalam penelitiannya, Rollick (2009) berpendapat bahwa peserta didik kesulitan memahami konsep dan mengidentifikasi transformasi. Hal ini sejalan dengan penelitian Morris \& Paulsen (2011), beberapa peserta didik sudah bisa menyelesaikan transformasi untuk objek geometri yang sederhana, akan tetapi mereka kesulitan pada permasalahan rotasi dan refleksi untuk bangun yang lebih kompleks.

Kasus seperti ini juga ditemukan di Indonesia, misalnya di MAN 1 Bukittinggi. Data ini dilakukan tanggal 08-13 Agustus 2016 dengan memberikan angket peserta didik kelas XI dan 
wawancara beberapa guru matematika. Hasil dari kegiatan tersebut memperoleh informasi bahwa materi transformasi merupakan materi matematika yang sulit dipahami oleh peserta didik. Beberapa guru matematika menyatakan bahwa peserta didik kesulitan dalam memahami arah suatu objek geometri yang ditransformasikan dan menjabarkan buktinya secara aljabar.

Selama ini, peserta didik belajar menggunakan buku matematika Kemendikbud RI dalam proses pembelajaran. Pada materi transformasi, perubahan posisi, bentuk atau ukuran suatu objek geometri yang ditransformasikan ditandai dengan tanda panah. Namun, kebanyakan peserta didik kesulitan memahami tanda tersebut dengan benar.

Guru matematika juga mengungkapkan bahwa media pembelajaran telah difungsikan saat proses pembelajaran dengan menampilkannya melalui proyektor infocus, sedangkan peserta didik mendengarkan penjelasan dari guru. Namun, guru juga mengakui bahwa media pembelajaran yang ada kurang mewakili materi transformasi. Biasanya, media tersebut diperoleh dari internet dan penyajiannya belum memfasilitasi peserta didik dalam memahami materi pelajaran.

Peserta didik membutuhkan visualisasi pada materi transformasi yang lebih praktis, efektif dan waktu belajar lebih dioptimalkan. Kebutuhan visualisasi tersebut dapat terpenuhi dengan proses pembelajaran berbantuan media pembelajaran berbasis komputer. Media pembelajaran sebagai sarana penting yang dapat memperjelas penyajian informasi dalam proses pembelajaran. Perubahan posisi, ukuran atau bentuk dari objek yang ditransformasikan melalui pergerakan animasi.

Media pembelajaran yang telah dirancang pada penelitian ini adalah media pembelajaran matematika berbasis komputer menggunakan program macromedia flash 8 . Penyajian materi pelajaran dimulai dengan memberikan permasalahan. Kemudian, peserta didik mengamati ilustrasi pada media pembelajaran. Dari ilustrasi, peserta didik menyelesaikan pertanyaan pada media sebagai bantuan peserta didik dalam memahami materi yang dipelajari. Peserta didik mengumpulkan informasi dari pertanyaan dengan berdiskusi, kemudian mereka menganalisis jawabannya. Hasil jawaban tersebut disampaikan di kelas.

Berdasarkan uraian tersebut, maka dirancang dan dikembangkan media pembelajaran yang dapat meningkatkan hasil belajar dan aktivitas belajar peserta didik. Penelitian pengembangan ini berjudul "Tahap Preliminary Research Pengembangan Media Pembelajaran Matematika Berbasis Komputer pada Materi Transformasi Kelas XI SMA/MA".

\section{METODE}

Jenis penelitian yang diterapkan adalah penelitian pengembangan model Plomp. Model ini terdiri dari tiga fase, yaitu penelitian pendahuluan, pembuatan prototipe dan fase penilaian. Artikel ini hanya membahas tahap penelitian pendahuluan atau preliminary research. Pada penelitian pendahuluan dilakukan analisis kebutuhan, analisis kurikulum, analisis konsep dan analisis peserta didik. Data tahap ini diperoleh melalui wawancara dengan beberapa guru matematika, angket peserta didik kelas XI di MAN 1 Bukittinggi dan studi literatur mengenai karakteristik peserta didik. Pada penelitian 
pendahuluan dianalisis menggunakan teknik deskriptif.

\section{HASIL DAN DISKUSI}

Hasil tahap penelitian pendahuluan dijabarkan sebagai berikut.

\section{Analisis kebutuhan}

Analisis kebutuhan adalah pengumpulan informasi yang dibutuhkan dalam pengembangan media pembelajaran matematika berbasis komputer pada materi transformasi. Pengumpulan informasi dilakukan di MAN 1 Bukittinggi pada tanggal 08-13 Agustus melalui kegiatan wawancara dengan guru matematika. Peneliti juga menyebarkan angket kepada 68 orang peserta didik di kelas XI IPA.

Informasi yang diperoleh pada tahapan ini adalah kebutuhan peserta didik dalam menerapkan kurikulum 2013 secara optimal dan media saat proses pembelajaran. Kebutuhan tersebut dapat terpenuhi dengan adanya media pembelajaran berbasis komputer. Hal ini dipilih karena peserta didik dapat mengoperasikan komputer, menyukai belajar berbantuan komputer, memudahkan presentasi.

Desain media pembelajaran yang direkomendasikan oleh guru dan peserta didik adalah kelengkapan materi translasi, pemanfaatan, kemudahan, kemenarikan tampilan berupa gambar/animasi dan warna yang bervariasi, memfasilitasi peserta didik belajar mandiri, soal-soal yang logis, memiliki menu-menu, tombol navigasi yang berfungsi, serta waktu belajar dapat dimaksimalkan.

\section{Analisis kurikulum}

Analisis kurikulum dilakukan dengan menelaah kurikulum 2013 untuk mata pelajaran matematika SMA/MA di kelas XI pada semester II. Tidak ada perubahan pada kompetensi dasar yang telah ditetapkan di silabus, namun pada indikator pencapaian kompetensi terdapat perubahan dalam susunan rumusan untuk materi transformasi.

Tujuan pembelajaran yang harus dicapai oleh peserta didik meliputi: (1) menjelaskan sifat-sifat transformasi; (2) menentukan penyelesaian masalah yang berkaitan dengan transformasi dengan pendekatan koordinat; (3) menganalisis konsep transformasi dalam menyelesaikan masalah; (4) menggambar objek geometri berupa titik, garis, bidang atau kurva yang ditransformasikan; dan (5) menyelesaikan permasalahan nyata yang berkaitan dengan aturan transformasi.

Alokasi waktu yang ditetapkan pada silabus terdapat perubahan dari 8 JP menjadi 12 JP @ 45 menit. Hal ini karena alokasi waktu yang ditetapkan pada silabus terlalu singkat dan dilihat dari kerumitan materinya.

\section{Analisis konsep}

Analisis konsep dilakukan dengan mengidentifikasi dan menyusun secara sistematis konsep utama yang akan dipelajari pada materi transformasi. Pembahasan materi transformasi dimulai dengan konsep yang sederhana sampai kepada konsep yang kompleks. Konsep utama pada materi transformasi adalah (1) translasi, (2) refleksi, (3) rotasi dan (4) dilatasi disesuaikan dengan kompetensi dasar.

Urutan ini dipilih karena suatu objek geometri yang ditransformasikan diawali dengan (1) perubahan posisi dengan menggesernya sesuai arah dan jarak tertentu; (2) perubahan posisi dengan 
mencerminkan suatu objek geometri sesuai dengan sifat-sifat pencerminan; (3) perubahan posisi dengan memutar suatu objek geometri sesuai titik pusat dan sudut putar; serta (4) perubahan posisi dan ukuran dengan memperbesar atau memperkecil suatu objek geometri sesuai titik pusat dan faktor skala. Peta konsep materi transformasi dilihat pada Gambar 1.

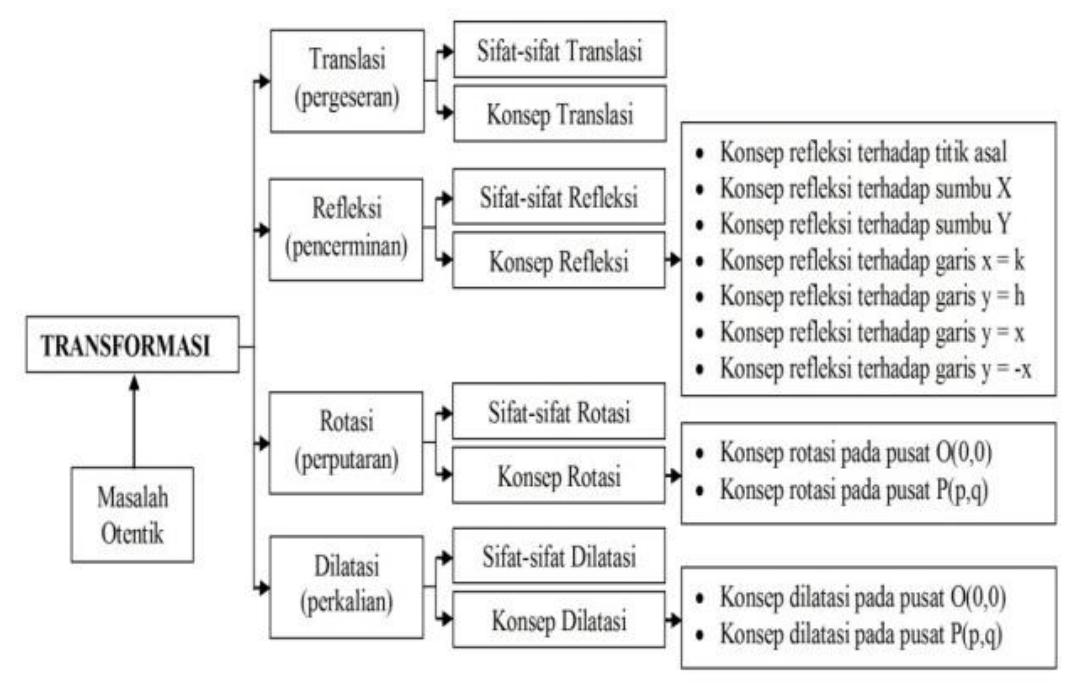

Gambar 1. Peta Konsep Materi Transformasi

\section{Analisis peserta didik}

Analisis peserta didik dilakukan untuk mengetahui karakteristik peserta didik meliputi: kemampuan akademis, usia, kecenderungan belajar dan kesukaan peserta didik terhadap warna. Peserta didik kelas XI IPA di MAN 1 Bukittinggi memiliki kemampuan akademis yang bervariasi, meliputi kemampuan tinggi, sedang dan rendah.

Pemilihan kriteria peserta didik ini didasarkan pada pertimbangan guru. Hasil nilai mid semester II di tahun ajaran 2016/2017 pada kelas XI IPA 1 menunjukkan bahwa terdapat 6 orang tinggi, 23 orang sedang dan 5 orang rendah. Sedangkan peserta didik kelas XI IPA 4 menunjukkan bahwa terdapat 6 orang tinggi, 21 orang sedang dan 6 orang rendah.

Kebanyakan peserta didik yang duduk di kelas XI memiliki usia 16-17 tahun. Menurut teori kognitif Piaget dalam Darmadi (2017) menyatakan bahwa peserta didik sudah mampu berpikir abstrak, logis, menarik kesimpulan, menafsirkan dan mengembangkan hipotesis. Namun, kenyataannya peserta didik masih membutuhkan suatu bentuk konkrit dalam memahami materi pelajaran, sehingga dikembangkan media pembelajaran.

Kebanyakan peserta didik lebih menyukai aktivitas belajar secara bersama-sama. Peserta didik dikelompokkan dalam pelaksanaan proses pembelajaran berbantuan media. Guru matematika dan peserta didik memberikan respon yang positif saat ditawarkan media pembelajaran berbasis komputer.

Desain media pembelajaran yang direkomendasikan oleh guru dan peserta didik adalah kelengkapan materi transformasi, mengutamakan pemanfaatan, kemudahan, kemenarikan tampilan berupa gambar, animasi dan warna, memfasilitasi peserta didik belajar mandiri, soal logis, memiliki menu-menu dan tombol navigasi, serta waktu belajar dapat dimaksimalkan. 
Kesukaan peserta didik terhadap warna berlandaskan pada psikologi warna. Menurut Waikins (2001) dalam Nugroho (2015), warna yang banyak disukai oleh manusia adalah warna biru. Hal ini sejalan dengan hasil angket peserta didik yang menunjukkan bahwa sebanyak 45 dari 65 orang peserta didik lebih suka dengan warna biru. Warna dipilih sebagai warna dominan untuk media pembelajaran. Warna biru berkaitan dengan kecerdasan, komunikasi, kepercayaan, efisiensi, ketenangan, logika, kesejukan dan sensitif.

\section{KESIMPULAN}

Berdasarkan hasil analisis-analisis pada penelitian pendahuluan, diperoleh informasi mengenai gambaran dari media pembelajaran matematika. Perancangan ini telah menghasilkan media pembelajaran matematika berbasis komputer pada materi transformasi pada tahap penelitian pendahuluan.

\section{UCAPAN TERIMA KASIH}

Terima kasih kepada dosen-dosen Pascasarjana Universitas Negeri Padang, kepala sekolah dan guru matematika di MAN 1 Bukittinggi.

\section{REFERENSI}

Edwards, L.D. 1997. Explore Ring the Terrority Before Proof: Students' Generalization in a Computer Microworld for Transformation Geometry. International Journal of Computer for Mathematical learning, pp 187.

Rollick, M. B. 2009. Toward a Deffinition of Reflection. Jurnal Mathematics Teaching in the Middle School. Vol 7, pp 397.

Morris, T. \& Paulsen, R. 2011. Using Tracing Paper to Teach Transformation Geometry. Jurnal Amesa. ISBN 978-0-620-47379-8. Johannensberg: Amesa, pp 129.

Darmadi, H. 2017. Pengembangan Model dan Metode Pembelajaran dalam Dinamika Belajar Siswa. ISBN 978-692-802-935-5. Yogyakarta: Penerbit Gava Media, pp 12.

Nugroho, Sarwo. 2015. Manajemen Warna dan Desain. Ed. 1. ISBN 978-979-29-5404-3. Yogyakarta: Andi Offset, pp 59-62. 